\title{
ALTERATIONS IN THE UTERINE ENVIRONMENT PRODUCED BY IUDS
}

\author{
T. R. WRENN, JOAN R. WOOD AND J. BITMAN \\ U.S. Department of Agriculture, Animal Husbandry Research Division, \\ Agricultural Research Center, Beltsville, Maryland 20705, U.S.A.
}

(Received 12th Fuly 1968, accepted 24th September 1968)

\begin{abstract}
Summary. Biochemical analyses near the time of expected blastocyst implantation showed that IUDs had marked effects on glycogen, RNA, DNA and histamine concentration of the rat uterus. All of these biochemical constituents except histamine were found to be significantly greater in uterine horns bearing IUDs than in contralateral control horns. Concentration of histamine was significantly lower in the IUD horn. There was little evidence that inflammation was present in horns bearing the devices.
\end{abstract}

\section{INTRODUCTION}

IUD-induced changes in the chemical composition of the uterus have been repeatedly investigated for a possible role in the mechanism of IUD contraceptive action (Kar, Kamboj, Goswami \& Chowdhury, 1965b; Kar, Chowdhury, Kamboj, Chandra \& Chowdhury, 1965a; Kwak, 1965; Glasser, 1967; Potts \& Pearson, 1967; Hall, Sedlis, Chabon \& Stone, 1965; Parr, 1966, 1967; Parr \& Segal, 1966; Kar \& Kamboj, 1964; Kar, Goswami, Kamboj \& Chowdhury, 1964; Ledger \& Bickley, 1966; Bonney, Glasser, Clewe, Noyes \& Cooper, 1966). Many of these observations have depended on subjective histological assessment or were carried out using material for which adequate controls were not available (for reviews, see Guttmacher, 1965; Marston \& Kelly, 1966; Corfman \& Segal, 1968).

The recent development in our laboratory of a method for the cervical introduction of an IUD lying wholly within the lumen of one uterine horn of the albino rat has provided an experimental preparation that facilitates studies of chemical differences between the infertile IUD horn and the contralateral horn possessing normal fertility (Wrenn, Wood \& Bitman, 1968). This method avoids the trauma of surgery and the associated inflammatory alterations involved in placing a suture through the walls of the uterus. The success of the technique in preventing pregnancy is currently $94 \%$ for rats that retain the IUD. The overall retention rate of all unilaterally fitted IUDs in our colony has been about $85 \%$.

Since the critical time of IUD action in rats appears to be on Days 4 and 5 
following mating (Doyle \& Margolis, 1964; Marston \& Chang, 1964; Greenwald, 1965), this time period was selected as the most appropriate for a search for physical and chemical differences that could be correlated with IUD-induced sterility.

\section{MATERIALS AND METHODS}

Nylon double S-shaped IUDs were inserted in one horn of 176 adult Wistar rats using the transcervical approach (Wrenn et al., 1968). The rats were kept in a controlled light environment of $12 \mathrm{hr}$ of continuous fluorescent illumination and $12 \mathrm{hr}$ of darkness. The rats were mated after the IUDs had been in the uterus for at least 1 month. The day on which copulation plugs were found

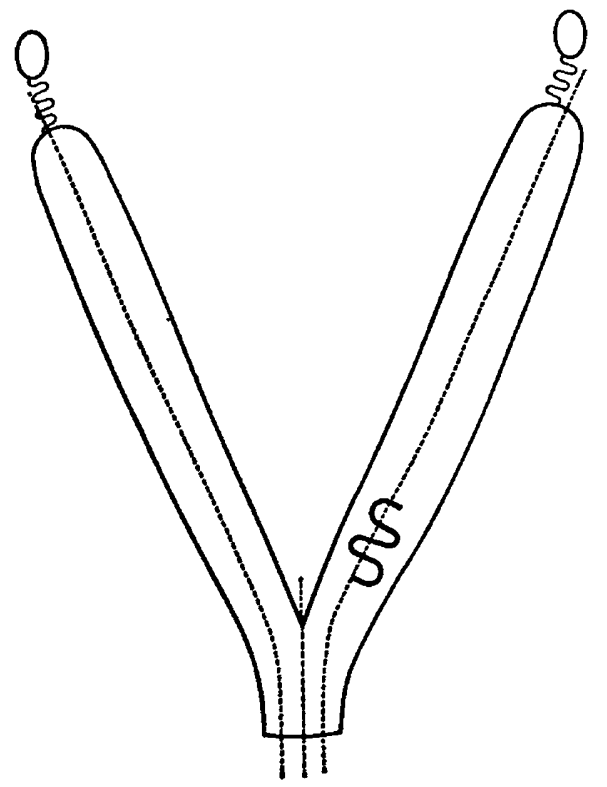

Texr-FIG. 1. Diagrammatic representation of the uterus, showing division of IUD and control horns for wateriand histamine, glycogen, nucleic acid or trypan blue samples.

following overnight mating was designated as Day 1 of pregnancy. The animals were killed by decapitation on the 4th day following mating, between 11.00 and 14.00 hours. The IUD and the contralateral control horns were split longitudinally into two samples as shown schematically in Text-fig. 1. One-half of each horn was used for a dry weight determination by reweighing after drying overnight at $100^{\circ} \mathrm{C}$ in vacuo; the other half of each horn was utilized for histamine, glycogen or nucleic acid determinations, or for trypan blue permeability studies. In other rats, glycogen and water analyses were performed on myometrial samples obtained after gently removing the endometrium by scraping with a scalpel.

In a group of twenty-six rats, uteri were sampled in a manner designed to characterize more exactly the location of IUD-induced changes in water, 
histamine and glycogen. The IUD horn was cut into halves transversely (Text-fig. 2), so that one sample consisted entirely of the uterine area containing the IUD (Part A). The other sample comprised the horn area distal to the IUD (Part B). The contralateral (control) horn was similarly divided (Parts $\mathrm{C}$ and D).

Histamine concentration was determined by the fluorometric method of Shore, Burkhalter \& Cohn (1959), using a Farrand Model A fluorometer. Glycogen was determined by the colorimetric anthrone method (Seifter, Dayton, Novic \& Muntwyler, 1950), with a Bausch and Lomb Spectronic 20 colorimeter at $625 \mathrm{~m} \mu$. Differences in tissue permeability caused by the presence of an IUD were studied by colorimetric measurements of trypan blue accumulation in the horns $30 \mathrm{~min}$ after intravenous administration of a $2 \%(0.35 \mathrm{mg}$ trypan blue/100 $\mathrm{g}$ body $\mathrm{wt}$ ) solution (Judah \& Willoughby, 1962; Cecil, Hannum \&

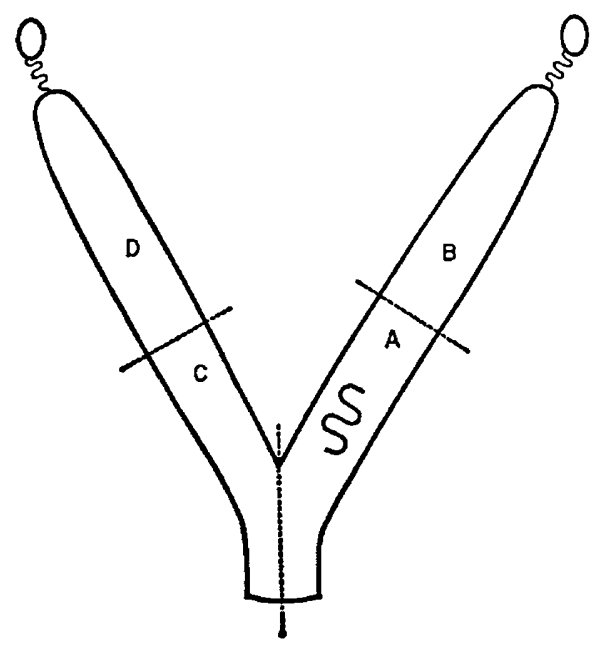

TeXT-FIG. 2. Division of uterus to determine location of IUD-induced changes in water, histamine and glycogen. A, IUD area; B, distal area; C, IUD contralateral (control) area; $D$, distal contralateral (control) area.

Bitman, 1966). For DNA and RNA analysis, samples were homogenized in cold $5 \%$ trichloroacetic acid as described by Schneider (1945). DNA was determined by the Dische diphenylamine method (Volkin \& Cohn, 1954), and RNA estimated from ribose content determined by the orcinol procedure (Brown, 1946). The results were analysed by Student's $t$ test, with correction for unequal group size.

\section{RESULTS}

The presence of an IUD produced increases in weight, water, glycogen and nucleic acids and a decrease in histamine concentration (Table 1). Horn weight and glycogen concentration were about $30 \%$ higher in horns containing devices, while histamine content declined about $20 \%$. Although the nucleic acid content increased significantly, increases in both cytoplasmic and nuclear 
constituents evidently occurred, the mean ratio of RNA to DNA not being significantly different for the two horns (1.34 for the control versus 1.38 for the IUD horn).

Table 2 shows the results obtained for twenty-six rats in which the uterine horns were divided transversely to compare the immediate environment of the

TABLE 1

COMPARISON OF VARIOUS UTERINE HORN PARAMETERS WITH AND WITHOUT IUDS

\begin{tabular}{|c|c|c|c|c|c|c|c|}
\hline Horn & $\begin{array}{c}\text { Wet } \\
\text { weight } \\
(m g)\end{array}$ & $\stackrel{\%}{\%}$ & $\begin{array}{c}\text { Glycogen } \\
(\mu g / 100 \mathrm{mg} \\
\left.D . W .^{*}\right)\end{array}$ & $\begin{array}{c}\text { Histamine } \\
(\mu g / 100 \mathrm{mg} \\
D . W .)\end{array}$ & $\begin{array}{c}R \mathcal{N} A \\
(\mu g / 100 m g \\
D . W .)\end{array}$ & $\begin{array}{c}D \mathcal{N A} \\
(\mu g / 100 \mathrm{mg} \\
D . W .)\end{array}$ & $\begin{array}{c}\text { Trypan blue } \\
(\mu g / 100 \mathrm{mg} \\
\text { D.W. })\end{array}$ \\
\hline $\begin{array}{l}\text { Control } \\
\text { IUD }\end{array}$ & $\begin{array}{l}266 \pm 5 \\
359 \pm 7\end{array}$ & $\begin{array}{l}80.4 \pm 0.2 \\
81 \cdot 1 \pm 0.1\end{array}$ & $\begin{array}{l}390 \pm 16 \\
506 \pm 23\end{array}$ & $\begin{array}{l}3 \cdot 64 \pm 0.20 \\
2.92 \pm 0.24\end{array}$ & $\begin{array}{l}3332 \pm 85 \\
3699 \pm 96\end{array}$ & $\begin{array}{l}2484 \pm 60 \\
2677 \pm 58\end{array}$ & $\begin{array}{l}29 \cdot 3 \pm 1.3 \\
32 \cdot 9 \pm 1 \cdot 7\end{array}$ \\
\hline $\begin{array}{l}\text { No. of uteri } \\
\text { observed } \\
P\end{array}$ & $\begin{array}{c}162 \\
<0 \cdot 001\end{array}$ & $\begin{array}{c}114 \\
<0.001\end{array}$ & $\begin{array}{c}24 \\
<0.001\end{array}$ & $\begin{array}{c}19 \\
<0 \cdot 050\end{array}$ & $\begin{array}{c}24 \\
<0 \cdot 010\end{array}$ & $\begin{array}{c}24 \\
<0.050\end{array}$ & $\begin{array}{l}25 \\
\text { NS }\end{array}$ \\
\hline
\end{tabular}

Values are means \pm S.E. $\quad$ NS $=$ non-significant.

* D.W. = expressed on a dry weight basis.

TABLE 2

GLYGOGEN, HISTAMINE AND PERGENTAGE WATER GHANGES IN VARIOUS SEGMENTS OF RAT UTERI CONTAINING AN IUD

\begin{tabular}{|c|c|c|c|c|}
\hline $\begin{array}{l}\text { Uterine location } \\
\text { (see Text-fig. } 2)\end{array}$ & $\begin{array}{c}\text { Letter } \\
\text { designation }\end{array}$ & $\begin{array}{c}\text { Glycogen } \\
(\mu g / 100 \mathrm{mg} \\
\left.D . W .^{*}\right)\end{array}$ & $\begin{array}{l}\text { Histamine } \\
(\mu g / 100 \mathrm{mg} \\
\left.D . W .^{*}\right)\end{array}$ & $\stackrel{\%}{\%}$ \\
\hline $\begin{array}{l}\text { IUD horn } \\
\text { IUD area } \\
\text { Distal area }\end{array}$ & $\begin{array}{l}\text { A } \\
\text { B }\end{array}$ & $\begin{array}{l}612 \pm 32 \\
495 \pm 26\end{array}$ & $\begin{array}{l}2.93 \pm 0.25 \\
1.94 \pm 0.22\end{array}$ & $\begin{array}{l}82 \cdot 0 \pm 0 \cdot 5 \\
81 \cdot 1 \pm 0 \cdot 4\end{array}$ \\
\hline $\begin{array}{l}\text { Control horn } \\
\text { IUD contralateral area } \\
\text { Distal contralateral area }\end{array}$ & $\begin{array}{l}\mathrm{C} \\
\mathrm{D}\end{array}$ & $\begin{array}{l}484 \pm 30 \\
405 \pm 22\end{array}$ & $\begin{array}{l}3 \cdot 49 \pm 0.27 \\
2 \cdot 45 \pm 0.21\end{array}$ & $\begin{array}{l}81 \cdot 2 \pm 0 \cdot 6 \\
80 \cdot 8 \pm 0 \cdot 4\end{array}$ \\
\hline Statistical difference $\dagger$ & & $\underset{\mathrm{BD}}{\mathrm{AB}, \mathrm{AC}, \mathrm{AD},}$ & $\mathrm{AB}, \mathrm{BC}, \mathrm{CD}$ & - \\
\hline
\end{tabular}

Values are means \pm S.E. Each mean represents a total of eight to ten animals.

* The concentration of glycogen and histamine was expressed on a dry weight basis by utilizing the mean dry weight of similar tissue of rats killed on the same day as those for the glycogen or histamine determinations.

$\uparrow$ Paired letters indicate that a significant difference exists between these uterine segments, $P<0.025$.

IUD with the more remote parts of the horn. The glycogen concentration in the vicinity of the IUD was significantly greater than in the more remote area of this horn and also significantly greater than in any other portion of the contralateral horn, being $26 \%$ higher than in the comparable location in the non-IUD horn. Differences between locations were not significant in the control horn. The concentration of histamine was significantly greater in the proximal parts than in the ovarian segments of each horn. Considerably more histamine (about 20\%) was present, however, in the contralateral horn than in the IUD 
horn. The area containing the IUD had the highest water content but this difference was not significant.

Since the IUD might have induced different chemical alterations in the glandular endometrium and the muscular myometrium, separate analyses were carried out on the myometrial samples remaining after the scraping procedure (see Table 3, which also shows horn weights before and after scraping).

TABLE 3

UTERINE GLYCOGEN, PERCENTAGE WATER AND HORN WEIGHT WITH ENDOMETRIUM REMOVED BY SGRAPING

\begin{tabular}{l|c|c|c|c|c}
\hline \multicolumn{1}{c|}{ Horn } & $\begin{array}{c}\text { Glycogen } \\
(\mu g / 100 \mathrm{mg} \\
D . W . \dagger)\end{array}$ & $\begin{array}{c}\% \\
\text { water }\end{array}$ & $\begin{array}{c}\text { Before } \\
\text { scraping }\end{array}$ & $\begin{array}{c}\text { After } \\
\text { scraping }\end{array}$ & $\begin{array}{c}\text { Weight of scraped } \\
\text { material }(\mathrm{mg})\end{array}$ \\
\hline $\begin{array}{l}\text { Control } \\
\text { IUD }\end{array}$ & $\begin{array}{c}447 \pm 16 \\
495 \pm 13\end{array}$ & $\begin{array}{c}79.7 \pm 0.3 \\
80.6 \pm 0.2\end{array}$ & $\begin{array}{c}244 \pm 10 \\
320 \pm 13\end{array}$ & $\begin{array}{c}221 \pm 9 \\
288 \pm 12\end{array}$ & $\begin{array}{c}23 \pm 2 \\
32 \pm 2\end{array}$ \\
\hline $\begin{array}{l}\text { No. of uteri observed } \\
P\end{array}$ & $\begin{array}{c}19 \\
<0.050\end{array}$ & $\begin{array}{c}19 \\
<0.025\end{array}$ & $\begin{array}{c}19 \\
<0.001\end{array}$ & $\begin{array}{c}19 \\
<0.001\end{array}$ & $<0.005$ \\
\hline
\end{tabular}

* Calculated by difference, i.e. horn weight before scraping minus weight after scraping.

$\dagger$ D.W. = dry weight.

TABLE 4

GLYCOGEN AND HISTAMINE OF IUD AND CONTROL HORNS EXPRESSED AS $\mu \mathrm{G}$ PER 100 MG OF WET TISSUE AND $\mu$ G PER ENTIRE HORN

\begin{tabular}{|c|c|c|c|c|}
\hline \multirow[b]{2}{*}{ Horn } & \multicolumn{2}{|c|}{ Glycogen } & \multicolumn{2}{|c|}{ Histamine } \\
\hline & $\begin{array}{l}\mu \mathrm{g} / 100 \mathrm{mg} \\
\text { wet tissue }\end{array}$ & $\mu g /$ horn & $\begin{array}{l}\mu g / 100 \mathrm{mg} \\
\text { wet tissue }\end{array}$ & $\mu g /$ horn \\
\hline $\begin{array}{l}\text { Unscraped } \\
\text { Control } \\
\text { IUD }\end{array}$ & $\begin{array}{l}78 \pm 3 \\
96 \pm 4\end{array}$ & $\begin{array}{l}196 \pm 11 \\
332 \pm 28\end{array}$ & $\begin{array}{l}0.71 \pm 0.04 \\
0.55 \pm 0.04\end{array}$ & $\begin{array}{l}1 \cdot 70 \pm 0 \cdot 14 \\
1 \cdot 81 \pm 0 \cdot 15\end{array}$ \\
\hline $\begin{array}{l}\text { No. of uteri observed } \\
P\end{array}$ & $\begin{array}{c}25 \\
<0.001\end{array}$ & $\begin{array}{l}25 \\
<0.001\end{array}$ & $\begin{array}{c}19 \\
<0 \cdot 025\end{array}$ & $\begin{array}{c}19 \\
\text { NS }\end{array}$ \\
\hline $\begin{array}{l}\text { Scraped } \\
\text { Control } \\
\text { IUD }\end{array}$ & $\begin{array}{l}90 \pm 3 \\
96 \pm 2\end{array}$ & $\begin{array}{l}199 \pm 24 \\
274 \pm 11\end{array}$ & - & - \\
\hline $\begin{array}{l}\text { No. of uteri observed } \\
P\end{array}$ & $\begin{array}{l}19 \\
\text { NS }\end{array}$ & $\begin{array}{c}19 \\
<0.025\end{array}$ & 二 & 二 \\
\hline
\end{tabular}

Values are means \pm S.E.; NS = non-significant.

The IUD caused significant increases in glycogen concentration, percentage water, and horn weight in the myometrial portion of the IUD-containing horns. The percentage of the total horn weight removed by scraping (endometrium) was similar in the IUD and control horns ( 10.0 versus $9.4 \%$, respectively). Since total weight of the IUD horn was increased (Table 1), it can be concluded that the IUDs produced similar changes in both the endometrium and myometrium. 
Since the IUD induced increases in uterine weight as well as changes in concentration of glycogen and histamine, these constituents were also calculated per wet weight and per total horn, to reflect total changes in uterine content (Table 4). The IUDs caused an increase in glycogen concentration, which, coupled with that in uterine weight, resulted in a true increase of $70 \%$ in glycogen synthesis. Histamine, considered in the same way, was observed to show little actual change.

\section{DISCUSSION}

Our results demonstrate that an IUD produces marked alterations in the biochemical composition of the uterus. These changes were measured at the critical period just before expected implantation of the blastocysts. Growth of the uterus was greatly stimulated by IUDs as indicated by the $35 \%$ increase in gross wet weight of the freshly excised horns (Table 1), and the 30 and $39 \%$ increases in fresh weight of the myometrium and endometrium respectively (Table 4). The increases in glycogen concentration and water content were also characteristic growth changes. Other evidence that the IUD was a stimulus to growth is provided by the increases in RNA and DNA content (Table 1), and can be interpreted as indicating that more protein synthesis occurred. It is interesting to note that, even though the IUDs occupied a relatively small area of the uterine lumen, the weight, glycogen and histamine changes induced in the myometrium (scraped horn tissue) were about the same as in the entire uterus.

Table 5 demonstrates that $93 \%$ of the IUDs inserted were recovered when the rats were killed. Some migration evidently occurred, since almost all IUDs were recovered from the lower third of the horns after having been placed near the middle.

The increase in wet weight in our rats was not as great as the $85 \%$ reported by Parr \& Segal (1966), but their IUDs were silk sutures which were placed along the entire length of the uterine lumen in order to maximize changes. Examination of the data of Kar et al. (1965b), reveals that IUDs produced a 5 and $10 \%$ increase in weight respectively, in rats bearing IUDs for 25- and 200-day periods, although the authors attached little significance to this.

The increase in glycogen concentration in the IUD horn confirms an earlier report of Parr (1966) concerning epithelial glycogen. Using histochemical techniques, he reported an accumulation of glycogen in the epithelium of the IUD horn, and its absence from the epithelium of the control horn. The site of glycogen increase was localized in the present study by separate analyses of whole horn and myometrium, and a significant increase in glycogen concentration was demonstrated in the myometrial tissue due to the presence of the device (Table 3). The glycogen contribution of the endometrium of the control horn appeared to be small, but $18 \%$ of the total was contained in the endometrium of the IUD horns. Kar and his co-workers have also determined glycogen chemically (Kar \& Kamboj, 1964; Kar et al., 1965b), but did not find a significant difference in the glycogen content of IUD and control horns, possibly because of the large variability associated with their glycogen values.

The effects of IUDs on uterine glycogen and periodic acid-Schiff positive 
material has been examined in several other species. In quantitative studies of uterine glycogen concentration in rhesus monkeys bearing IUDs for 90 days, Kar et al. (1965a) found little difference from controls. Hall et al. (1965) reported no change in endometrial glycogen in humans with intra-uterine rings. Using similar methods in rabbits, Ledger \& Bickley (1966) found no increases in gland cell glycogen in horns having IUDs. The failure to observe glycogen increases in uteri containing IUDs might be due to lack of quantitative methodology or to differences in these species when compared with the rat.

The lower histamine concentration recorded on Day 4 of pregnancy in the IUD horn (Table 1) differs from the report of Parr (1967) who found that the concentration of histamine, on a wet weight basis, in the IUD horn was double that in the contralateral horn. The total amount of histamine (determined fluorometrically) in the uterine horns (Table 4) was 1.7 to $1.8 \mu \mathrm{g} / \mathrm{horn}$. This is four to ten times higher than the amount Parr determined using the guineapig ileum bio-assay. There appears to be no explanation for a difference of this magnitude.

\section{TABLE 5}

LOGATION AND PERGENTAGE RECOVERY AT AUTOPSY OF A TOTAL OF 176 MONAFILAMENT NYLON IUDS PREVIOUSLY INSERTED THROUGH THE CERVIX

\begin{tabular}{l|c|c|c|c|c}
\hline & \multicolumn{4}{|c|}{ Location of IUD in uterus } & \multirow{2}{*}{ Total } \\
\cline { 2 - 5 } & At cervix & Lower third & Middle third & Upper third & \\
\hline No. of IUDs found & 63 & 91 & 6 & 3 & 163 \\
\% of IUDs found & 38.7 & 55.8 & 3.7 & 1.8 & 100 \\
$\%$ recovery & 35.8 & 51.7 & 3.4 & 1.7 & 92.6 \\
\hline
\end{tabular}

Since chronic inflammation may be involved in the anti-fertility effect of IUDs (Greenwald, 1965; Parr, Schaedler \& Hirsch, 1967; Corfman \& Segal, 1968) considerable attention was given in this study to evidence of inflammation. One of the usual signs of inflammation in tissues is increased capillary permeability, and this was examined by means of the trypan blue technique. Although the IUD horn showed greater uptake of the dye, the difference was not statistically significant, suggesting that uterine vascular permeability may not be an important factor in IUD action.

Capillary permeability, of course, is only one indicator of inflammation and failure to note an increase does not preclude the presence of infection. Preliminary results of work now in progress show a significantly higher packed cell volume from uterine exudate of non-pregnant IUD horns contralateral to 14-day pregnant horns than in similar horns of 14-day pseudopregnant rats. The incidence of uterine exudate in this experiment was low, only $4.3 \%$ of the IUD horns showing visible amounts. In a previous study (Wrenn et al., 1968), $54 \%$ of the IUD horns contained exudate in 10- to 21 -day pregnant rats. This suggests that the rat may be more susceptible to infection and/or inflammatory reaction during later pregnancy than at earlier times, and seems to merit further investigation.

The distinct differences shown in the biochemistry of the IUD and control 
horns of rats may aid in the understanding of IUD action. Since the chemical components of the uterus that are altered by IUDs are also markedly affected by oestrogen, future experiments will be designed to determine the influence of oestrogen on these constituents in the presence of IUDs.

\section{REFERENCES}

Bonney, W. A., JR, Glasser, S. R., ClewE, T. H., Noyes, R. W. \& Cooper, C. L. (1966) Endometrial response to the intrauterine device. Am. F. Obstet. Gynec. 96, 101.

Brown, A. H. (1946) Determination of pentose in the presence of large quantities of glucose. Archs Biochem. 11, 269.

Cecil, H. G., Hannum, J. A., JR \& BrtMan, J. (1966) Quantitative characterization of uterine vascular permeability changes with estrogen. Am. F. Physiol. 211, 1099.

Corfman, P. A. \& Segal, S. J. (1968) Biologic effects of intrauterine devices. Am. F. Obstet. Gynec. 100, 448.

Doyre, L. L. \& Margolis, A. J. (1964) Intrauterine foreign body. I. Effect on reproductive processes in the rat. Fert. Steril. 15, 597.

Glasser, S. R. (1967) Response of human endometrial lipid to the IUD. Fedn Proc. Fedn Am. Socs exp. Biol. 26, 536.

Greenwald, G. S. (1965) Interruption of pregnancy in the rat by a uterine suture. F. Reprod. Fert. $9,9$.

GurTMACHER, A. F. (1965) Intra-uterine contraceptive devices. F. Reprod. Fert. 10, 115.

Hall, H. H., Sedlis, A., Chabon, I. \& Stone, M. L. (1965) Effect of intrauterine stainless steel rings on endometrial structure and function. Am. F. Obstet. Gynec. 93, 1031.

JUDAH, J. D. \& WILloughBY, D. A. (1962) A quantitative method for the study of capillary permeability: Extraction and determination of trypan blue in tissues. F. Path. Bact. 83, 567.

Kar, A. B., Chowdhury, S. R.,'Kamboj, V. P., Chandra, H. \& Chowdhury, A. R. (1965a) Effect of an intrauterine contraceptive device on the uterus of rhesus monkeys. Int. F. Fert. 10, 321.

Kar, A. B., Goswam, A., KamboJ, V. P. \& Chowdhury, S. R. (1964) Effect of a foreign body on the response of the uterus of ovariectomized rats to estrogen. Steroids, 4, 159.

KAR, A. B. \& KAMBOJ, V. P. (1964) Effect of an intrauterine device on gestation in rats. Ind. F. exp. Biol. 2, 229.

Kar, A. B., Kamboj, V. P., Goswam, A. \& Chowdhury, S. R. (1965b) Effect of an intra-uterine contraceptive suture on the uterus and fertility of rats. F. Reprod. Fert.9, 317.

KWAK, H. M. (1965) Studies on the effects of intra-uterine contraceptive device: with particular reference to endometrial changes. Korean 7. Obstet. Gynec. 8, 253.

LEDGER, W.J. \& BrCKLEY, J. E. (1966) Effect of a plastic foreign body on the genital tract of the female rabbit. Obstet. Gynec., N.Y. 27, 658.

Marston, J. H. \& Chang, M. C. (1964) Action of intra-uterine foreign bodies in the rat and rabbit. Proc. 2nd Int. Conf. Intra-uterine Contraception, New York, p. 242.

Marston, J. H. \& Kelly, W. A. (1966) The effects and mode of action of intra-uterine devices. Vet. Rec. 79, 644 .

PARR, E. (1966) Glycogen accumulation in the rat uterus containing an intrauterine contraceptive device. Fert. Steril. 17, 797.

PARR, E. (1967) Histamine content of the rat uterus containing an IUCD. F. Reprod. Fert. 14, 321.

PARr, E. L., Schardler, R. W. \& Hirsch, J. G. (1967) The relationship of polymorphonuclear leukocytes to infertility in uteri containing foreign bodies. F. exp. Med. 126, 523.

Parr, E. L. \& SEgat, S. J. (1966) The effect of an intrauterine contraceptive device on the weight of the rat uterus. Fert. Steril. 17,648.

Potts, M. \& Prarson, R. M. (1967) A light and electron microscope study of cells in contact with intrauterine contraceptive devices. F. Obstet. Gynaec. Br. Commonw. 74, 129.

Schnemer, W. C. (1945) Phosphorus compounds in animal tissues. I. Extraction and estimation of desoxypentose nucleic acid and of pentose nucleic acid. F. biol. Chem. 161, 293.

Seifter, S., Dayton, S., Novic, B. \& Muntwrler, E. (1950) The estimation of glycogen with the anthrone reagent. Archs Biochem. 25, 191.

Shore, P. A., Burkhalter, A. \& Cohn, V. H., JR (1959) A method for the fluorometric assay of histamine in tissues. F. Pharmac. exp. Ther. 127, 182.

Vorknn, E. \& CoHN, W. E. (1954) Estimation of nucleic acids. In: Methods of Biochemical Analysis, Vol. I, p. 287. Ed. D. Glick. Academic Press, New York.

WRENN, T. R., Wood, J. R. \& BITMAN, J. (1968) A new technique for introducing IUDs into rat uteri. F. Reprod. Fert. 16, 515. 